\title{
O GIRO DOS OUTROS: FUNDAMENTOS E SISTEMAS NAS FOLIAS DE URUCUIA, MINAS GERAIS
}

\author{
Luzimar Paulo Pereira
}

\begin{abstract}
É. Eu é que estive lá, junto, nas horas, em estâncias tão desiguais. Ali, primeiro, com um, depois com o outro, depois com os todos dois, para todos o sol nascendo. Eu vi e ouvi, tudo o que conformemente era para se notar, que se deu: fui fragrante de testemunha... Agora, não sei...

João Guimarães Rosa, Estas estórias
\end{abstract}

Em Urucuia, um folião, num sentido estrito, é aquele que "faz folia", o agente fundamental da sua realização. Num sentido amplo, no entanto, "cantar" e "tocar" para uma festa religiosa não encerram as atividades do personagem. Ser folião também implica "gostar de folia", o que significa estar propenso a assistir, acompanhar e eventualmente participar, sem maiores compromissos, de festas que são feitas por diferentes foliões. Durante todo o meu trabalho de campo no município, as festividades que pude registrar contavam com a presença de pelo menos um destes tocadores, ali apenas para "ver e iscuitar" a "folia dos outros". As razões desta aparente ubiquidade eram oferecidas pelos próprios personagens para destacar a afeição do folião pela folia. $\mathrm{O}$ cantador e tocador é antes de tudo um devoto. A ideia não se refere somente às suas obrigações para com a festividade. ${ }^{1}$ Um devoto não é apenas aquele que deve um voto ao santo, mas também é a pessoa que nutre um verdadeiro gosto pelas festas a ele dedicadas (Pereira 2004, 2011a). "Ir numa folia" e "fazer uma folia", porque se gosta dela ou porque se está obrigado a ela, são expressões que evocam a existência de um poder agenciador — uma influência, na linguagem dos devotos - que condiciona a própria ideia do "ser folião" (Pereira 2008, 2012c).

A circulação dos foliões por diversas festas urucuianas tem como pano de fundo a existência de sociabilidades agonísticas no interior daquilo que, noutro lugar, denominei "comunidade festiva" (Pereira 2011a). Estendida para aquém e além dos limites administrativos do município, disputando 
precedência com outras "comunidades" concorrentes e, por vezes, complementares (a Igreja, o sindicato rural, a família etc.), a coletividade dos participantes das folias é constituída por meio de intensos deslocamentos de pessoas, palavras e coisas. O conflito não é, em absoluto, uma ameaça à vida comunitária ou festiva (ver Simmel 1971; Bailey 1971; Comerford 2003; Cavalcanti 2006, entre outros). A existência de feitiços lançados para prejudicar a atuação de cantadores e tocadores (Pereira 2011a), as narrativas difamatórias a respeito da existência de violeiros supostamente pactários do diabo (Pereira 2008, 2012c), os temidos encontros de folia (Pereira 2011a, 2012 b), entre outras práticas sociais compartilhadas, revelam um mundo no qual para "ser folião" uma pessoa precisa participar de constantes disputas por fama e renome. Um bom tocador urucuiano consolida sua atividade e sustenta sua reputação em oposição à - e, muitas vezes, em detrimento da — imagem de outros foliões (Pereira 2008, 2011a, 2012b, 2012c).

Na comunidade de folias urucuiana, as competições por nome e reconhecimento ocorrem a partir do esforço comparativo dos seus participantes. Neste sentido, como condição prévia para as lutas por reputação, os foliões precisam contar com certa matriz de inteligibilidade que lhes permita estabelecer semelhanças e diferenças entre os festejos (e entre todos os seus produtores). A noção nativa de fundamento indica, então, a ideia de que todas as folias conhecidas são apenas uma só, "no mundo todo". A festa, na opinião dos devotos, possuiria uma integridade primordial ao mesmo tempo em que é idêntica a si própria, onde e quando quer que aconteça. "Ir na folia dos outros", neste contexto, poderia ser explicado como um deslocamento em direção ao mesmo: uma atividade que reitera a existência de um modelo criado pelos Santos Reis Magos e transmitido aos homens desde "o tempo em que Jesus Cristo andou pela terra".

A noção de sistema, por outro lado, refere-se ao inverso. Embora seja apenas uma só, a folia também pode ser "outra". As diferenças entre os festejos, segundo os devotos, seriam resultados das criações particulares de pessoas ou grupos distintos. No linguajar urucuiano, há o sistema dos antigos e dos novos, assim como sistemas pessoais, familiares, típicos de uma vizinhança, de uma cidade, de uma microrregião e de um estado inteiro ("as folias de São Paulo têm um sistema diferente"). As variações são percebidas atentando-se para traços distintivos diversos: a música tocada por um grupo que é diferente da de outro, os comportamentos valorizados pelos devotos de um grupo ao contrário de outro, a indumentária particular usada por um grupo e não pelo outro etc. Enquanto o fundamento trata da unidade, daquilo que transforma a folia numa só e única coisa "no mundo todo", o sistema fragmenta para produzir alteridades, contribuindo para explicar a 
infindável capacidade de os festejos serem criados e recriados ao longo do tempo e através do espaço.

Neste texto, procuro analisar e descrever os diversos usos narrativos e festivos das noções de fundamento e sistema entre os foliões de Urucuia. Em especial, quero destacar o modo como ambos os conceitos estão relacionados a processos específicos de produção e contestação de uma experiência do sagrado calcada nas ideias de unidade e totalidade (Durkheim 2000). ${ }^{2}$ Propondo que as festas sejam uma e várias, que sejam inalteradas e mutantes, que sirvam aos interesses de uma coletividade e aos anseios mais mundanos de seus participantes individuados, os devotos põem em jogo demarcadores rituais - frames, na linguagem de Bateson (2000) - capazes de produzir contextualmente a confirmação do poder totalizador e atemporal das folias ao mesmo tempo em que abrem espaço para sua dissolução. Através do fundamento e dos sistemas, as festas urucuianas podem ser simultaneamente fenômenos da ordem da unidade e da diversidade.

\section{As festas do (em) movimento}

O vocábulo folia evoca a realização de longas jornadas festivas, por meio das quais grupos de cantadores e instrumentistas visitam, durante um período de tempo determinado pelo calendário religioso, as casas, as fazendas, os cemitérios e as igrejas de um território previamente estabelecido. Os deslocamentos - conhecidos como giros - são organizados com o intuito de coletar oferendas necessárias ao custeio de uma reza. Em troca do que é recolhido - dinheiro, sacas de arroz, feijão, animais de criação etc. — os viajantes distribuem, através de cantos e danças, bênçãos aos doadores, além de auxiliá-los no cumprimento de suas promessas e contribuir para que almoços, jantares e bailes sejam oferecidos em suas passagens.

Os grupos de cantadores e instrumentistas são conhecidos como ternos ou companhias e seus integrantes denominados foliões. As jornadas, entretanto, não se esgotam apenas com sua participação. Também encontramos durante suas realizações os imperadores (os patrocinadores dos festejos, para quem os foliões estão a "trabalho"), os moradores (a quem os foliões visitam em suas casas), os acompanhantes (devotos que cumprem a jornada ao lado dos foliões) e toda uma série de outros agentes igualmente importantes que participam de maneira ativa das rezas, dos cantos, dos almoços, dos jantares e dos momentos de sua preparação (os serventes, as cozinheiras, os convidados etc.). Todos eles compartilham com os cantadores e tocadores os códigos e os saberes cerimoniais necessários à produção das folias. Não se excluem 
entre os personagens dos festejos nem mesmo os mortos e os santos, com quem os foliões e os demais participantes acreditam interagir ao longo de um único giro. Mais do que apenas grupo precatório, do que apenas o terno ou a companhia, as folias são, como um todo, extensos rituais de trocas sociais e simbólicas. Nelas, homens e divindades, vivos e mortos, famílias e indivíduos, todos, enfim, se vêm articulados através de uma extensa rede em que pessoas, bens e serviços morais, religiosos, econômicos, estéticos etc. são postos em deslocamento, trocados, dados, recebidos e retribuídos (Mauss 2003).

A rigor, um giro de folia é um longo processo festivo (Pereira 2004, 2011a; Turner 1974; Van Gennep 1978).

a) A retirada - que ocorre na moradia dos imperadores - demarca, para seus participantes, o início oficial das festividades. A folia exibe-se, pela primeira vez, desde o último ciclo festivo, diante dos convidados. Os organizadores da festa começam a se preparar dias, semanas, meses e até anos antes da sua realização. Dinheiro é economizado e mantimentos são estocados. Além disso, redes de auxílio mútuo são costuradas e recosturadas de modo a garantir a mão de obra necessária à produção das festividades. Durante a retirada, um jantar é oferecido aos convidados. No final, diante do altar preparado para entronar o santo padroeiro da festa, cantos são realizados para que os foliões recebam - das mãos dos imperadores - os principais objetos cerimoniais de um giro: a bandeira, as toalhas e os instrumentos musicais (Pereira 2011b).

b) O giro propriamente dito pode ser descrito como a principal atividade dos foliões. A jornada define, por excelência, a festividade. Um devoto, ao ser questionado, nunca terá dúvidas em dizer: a festa "começa" quando o giro "começar". Realizada durante um, três, seis ou nove dias, a jornada é uma sucessão de visitas e pousos realizados nas residências dos devotos. Ali, os foliões cantam e brincam para abençoar os moradores e receber em troca oferendas diversas. Intercalada às atividades nas casas, há também o deslocamentos por estradas, trilhas rurais ou ruas de pequenos centros urbanos. Um giro urucuiano "tradicional" (aquele que "dá gosto", segundo os foliões) é feito a cavalo. Mas, a depender das distâncias que se quer percorrer, as viagens também podem ser feitas a pé ou em caminhonetes. Além de adentrar as casas dos devotos, os foliões também passam por cemitérios e igrejas, entendidos, cada um deles, como a morada dos mortos e a morada dos santos.

c) A entrega é o momento em que, depois de viajar com os tocadores e cantadores, a folia retorna à casa dos imperadores (para ser "entregue" a eles). Ao contrário da retirada, que conta com poucos convidados, geralmente vizinhos e parentes dos organizadores da festa, e ao contrário do giro, que 
ocorre com os foliões e um número restrito de acompanhantes, o encerramento das festividades destaca-se pela presença de inúmeros participantes. Ápice do processo festivo, a entrega propõe uma abertura, quando a moradia dos imperadores deve ser preparada para receber um número potencialmente infinito de convidados. Ali, como assegura a sabedoria compartilhada pelos devotos, "todo mundo pode entrar" para rezar, comer, beber, brincar e dançar. A entrega divide-se em algumas atividades centrais: a chegada dos folióes, o almoço ou jantar oferecido aos convidados, a reza da ladainha, a entrega da folia e a despedida. Em geral, o evento termina com um grande baile.

As folias urucuianas são verdadeiras festas em (e do) movimento. ${ }^{3} \mathrm{Em}$ duas direções concomitantes. As folias são festividades que vão ao encontro das pessoas. Centrados na viagem dos foliões, os giros implicam uma "saída" de um lugar familiar (a casa do imperador), a "passagem" por lugares distantes (as casas de outros moradores, igrejas e cemitérios) e um "retorno", final, ao mundo familiar onde tudo começou (a casa do imperador). ${ }^{4}$ Através dos deslocamentos, os santos padroeiros dirigem-se à moradia dos devotos para o estabelecimento de um tempo extraordinário (ver Brandão 1981). A expansão do sagrado, no entanto, articula-se com diversos momentos de contração. As festas também se estruturam por meio do deslocamento dos devotos ao encontro do seu santo padroeiro. O importante, da perspectiva de quem "vai para uma folia", é a passagem do ponto de partida da rotina até sua ruptura através de uma transposição espacial. As pessoas saem de suas casas e realizam deslocamentos para um lugar que se transforma no território festivo propriamente dito.

Os movimentos de contração e expansão inauguram um período de fartura, de gente, de bens econômicos e da presença do sagrado. Essa nova qualidade de tempo, como no caso das festas do divino descritas e analisadas por Contins e Gonçalves (2008), tem consequências "significativas sobre a vida individual e coletiva dos devotos" (:16). As trocas são mais intensas, os espaços se condensam e os encontros tornam-se muito mais frequentes. A exemplo do que ocorria com as variações sazonais na sociedade esquimó, analisadas por Mauss (2003), as folias estabelecem - ao longo do período de sua vigência - uma visão distinta acerca da vida das pessoas e das relações entre elas. O tempo dos festejos, em oposição ao tempo cotidiano, vem a ser marcado por um estado de exaltação religiosa contínua. A vida ganha um brilho diferente e as oposições entre o alto e o baixo, o passado e o presente, o nós e os outros, a casa e a rua, homens e mulheres, formalidade e informalidade, entre outras, são parcialmente desfeitas ou, pelo menos, momentaneamente mediadas (Pereira 2011a). 
Os giros são estruturados segundo um profundo sentido de reversibilidade. Cada folia é a reiteração necessária, por meio de dons e contradons, de uma relação que se pensa e se quer "eterna" entre santos e devotos. Num estudo sobre os festejos dos Reis realizados numa comunidade localizada na cidade do Rio de Janeiro, Daniel Bitter (2008) propõe que o ato de "co-memorar" não é apenas um gesto de "lembrar", mas, principalmente, o de "recuar de certo modo ao ponto original de fundação da ordem humana, ao plano oculto e invisível do universo" (:48). A memória não é, neste contexto, simplesmente uma função psicológica, mas emerge como instrumento mediador que permite o acesso a domínios distantes do mundo cósmico (Vernant 1990).

O caráter cíclico das festividades urucuianas mantém inúmeras semelhanças com suas congêneres cariocas. As festas realizam um retorno renovado às origens da criação, onde os devotos se encontram não apenas com os santos, mas também com as circunstâncias e forças que produziram e mantêm em pé o mundo social e cosmológico. As festividades, por esta razão, são sempre as mesmas, quando e onde quer que sejam realizadas. Segundo dizia um cantador, a folia é "uma só":

A folia dos Três Reis é só os Três Reis. [...] Tem muita folia no mundo porque os imperador é muito. E não dá conta pra sair pra todos os imperador do Brasil todo. Então cada um tem seu terno... Mas onde se encontra todo mundo, os folião é o mesmo, é um só, o terno de folia é sozinho, do mundo inteiro é um sozinho (Entrevista: Arcísio, Urucuia/MG).

O ímpeto cíclico e atemporal das folias urucuianas não parece, no entanto, ser capaz de apagar, na percepção dos devotos, o reconhecimento das suas transformações e diferenças através do tempo e ao longo do espaço. Cada retorno às origens da criação é também responsável pela realização de uma festa distinta, única. Os empreendimentos festivos produzem e também são produzidos pela diferença. Um giro de folia, a partir de um determinado ponto de vista, é sempre um evento singular, às vezes construído às expensas da opinião negativa a respeito de outro. Dizia um devoto:

Não é todos os imperador que faz isso, não. Tem uns aí que faz a janta, mas só serve na mesa dos folião. É maneira deles economizar na saída, né? Não gastar os recursos da festa, né? Mas isso não tá certo, não. Meu sistema aqui é diferente. Os folião come na mesa, mas quem quiser pode servi também. Depois que eles levanta tá aberto pra todo mundo. Pode servi à vontade, porque, graças a Deus e os Senhor Santo Reis, nunca faltou nada pra ninguém. A gente tá fazendo 
uma coisa de devoção, né? A gente recebeu um milagre, nóis tamo cumprindo um voto. Não pode ficar guardando. É pouquinho que a gente dá, mas sempre sobra, graças a Deus (João Bertoldo. Sons do Urucuia). ${ }^{5}$

Daí o vívido interesse dos participantes em comparar, avaliar, julgar e classificar os diversos giros em atuação. Não há atividade que mobilize mais os devotos urucuianos do que conversar a respeito das festas realizadas ao longo de um ano ou que marcaram suas lembranças. Embora, no limite, as folias sejam pensadas pelos seus participantes como reatualizações de uma única folia original (aquela ensinada pelos Magos), há o reconhecimento de que os grupos sociais por detrás de sua produção são outros, de que os interesses dos atores são diferentes e de que cada uma delas também vai produzir suas próprias histórias, fatos ou feitos extraordinários.

\section{O capitão e o fundamento}

Nas festas, o folião é o especialista ritual responsável pela realização das jornadas. Não há folia que ocorra sem sua presença. Embora seja possível, ainda que pouco provável, um festejo ser realizado sem um patrocinador instituído (o imperador), é impossível imaginarmos sua execução sem a figura do cantador e tocador integrante dos ternos de folia. Era o que me dizia, certa vez, um destes personagens.

Por isso chama folia, porque arreúne aqueles homens, com aqueles instrumento, tocando e cantando com aquela multidão acompanhando. Aí se chama de folia. É tanto que tem os folião, tem oito, dez folião. Aquele que tá com toalha se chama de folião: aquele que tá com os instrumento, que canta, que brinca, que tá com a toalha, que tá com a responsabilidade duma folia... aí virou uma folia. E aquele que acompanha uma folia com obediência ele se torna um folião também. É por isso chama de folia. A companhia ajuda: todo mundo é folião também, todo mundo tá acompanhando a folia. Agora, tem os responsável, aí chama de folia. Porque se fosse só reza e não tivesse ninguém pra cantá, não falá do santo, cantá os versos, cantá o passado, como é que foi a viagem dos Reis Magos de Oriente a Belém, como voltaro, aí é só reza: "vamo rezá pros três Reis Magos". Mas se sair cantando e tocando, é folia. A tradição é essa. É folia (Entrevista: Zé Wilson, Urucuia/MG).

Segundo meu interlocutor, todos que saem no giro são foliões em potencial, ainda que alguns o sejam mais do que outros. O cantador e tocador 
de fato e por direito, é aquele responsável por "lembrar", através de certas atividades específicas, o "tempo" dos Santos Reis. A memória vivida do "tempo dos Magos" - aquilo que define a folia em oposição a uma simples reza ao mesmo tempo em que distingue seus participantes - é conhecida pelos devotos como o fundamento. A noção implica a própria ideia de eficácia (Tambiah 1985; Mauss 2003). O fundamento está presente nos artefatos religiosos ("a bandeira é o fundamento"; "a toalha tem fundamento"; "a viola é do tempo dos Reis Magos"), nas falas padronizadas, nos gestos ritualizados, nos comportamentos observados, perpassando todos os domínios da festividade. A noção evoca o sagrado das formulações durkheimianas: "o centro irradiador em torno do qual gravita um grupo de crenças e de ritos, um culto particular" (Durkheim 2000:25). Uma folia sem fundamento não pode ser considerada uma folia, porque seria incapaz de realizar seu objetivo de estabelecer as trocas de dádivas entre homens e santos (Pereira 2004, 2011a).

Na linguagem dos devotos, o fundamento pode ser traduzido como uma coleção de saberes (relatos bíblicos, mitos, narrativas de casos etc.), que os foliões e devotos precisam aprender e resguardar de modo a garantir a realização "correta" das festividades. ${ }^{6}$ A noção estabelece os parâmetros mínimos a respeito do que deve ou não ser feito durante uma jornada. Conhecimento considerado primordial, absoluto e oriundo de um espaço-tempo imaginário, o fundamento remete às ideias de fundação, base, sustentação, além de ser derivado daquilo que é fundante, fundador, original e primevo (Pereira, 2004, 2011a). Também denominado "doutrina", "sentido" ou "seguimento", o conceito articula a unidade das folias "no mundo", reforçando seus laços primordiais com "antigos" foliões e com o evento mítico, conhecido por todos os devotos, da viagem dos Reis Magos em direção a Belém para adorar o Menino Jesus. ${ }^{7}$ Não se trata "apenas" de "cantar os reis" ou "viajar com fé". O fundamento envolve igualmente seguir o exemplo oferecido pelos santos. A semelhança entre o que teria sido feito e o que se faz é um dado primordial. Era o que dizia um capitão mineiro:

A gente tem as parte que a gente canta, tem aquelas ramagem todo certo que é o que a gente aprendeu dos mais velhos. Então, às vezes, quando a gente tá cantando num agradecimento, numa casa, a gente inventa verso, mas, numa apresentação sempre é os verso que foi dito pela época dos Reis. Vem da época do nascimento de Nosso Senhor Jesus Cristo, não é isso? Porque quando os Reis saíram, eles saíram pra poder fazer uma visita ao Menino Jesus. Depois da visita, é que eles tomaram o nome de foliões e saiu no mundo girando com a folia. É uma tradição que vem desde os Três Reis Magos (Corrêa, Marchi \& Saenger 2002:160). 
O fundamento - enquanto saber-fazer festivo ensinado pelos Magos precisa ser compartilhado por todos os participantes de uma folia; do contrário, não haveria como a festa ocorrer. ${ }^{8}$ No entanto, o conhecimento detalhado e aprofundado do repertório de histórias e exemplos que sustenta a realização das festividades é atributo principal do capitão. O líder do grupo de cantadores e tocadores - o "chefe dos foliões" - é o especialista que sabe, mais do que todos os outros, como e porque se faz uma festa. Durante meu trabalho de campo, pude perceber como os capitães urucuianos gostavam de me narrar pedaços compridos da história mítica dos três Reis Magos e descrever eventos supostamente ocorridos que comprovassem o poder religioso das folias. As falas eram uma maneira de legitimar sua condição de líder festivo, um modo de revelar seu esforço no sentido de adquirir o conhecimento ("eu pelejei pra aprender") e uma forma de garantir minha correta compreensão do fundamento ("O sentido da folia é esse aí"). Narrar as origens da folia "no mundo" e descrever os fatos extraordinários que comprovam sua eficácia também tinham o papel de designar o seu sentido primeiro - sua direção e rumo mais importantes. Falar do fundamento é dizer o que a festa é e como deve ser feita, além de indicar o porquê da sua existência.

O capitão urucuiano também é aquele em quem se reconhece uma capacidade incomum de reproduzir os versos necessários à condução dos reis, nome dado aos cantos cerimoniais que tornam possíveis as atividades mais importantes de uma folia (o termo "reis" também evoca seu mito de origem, afinal, foram os Reis Magos que inventaram a festa). Para realizar os cantos, os líderes dos cantadores e tocadores precisam conhecer as tabelas de folia, conjunto de textos poéticos (em forma de versos rimados) transmitido através da literatura oral ou por meio de pequenos cadernos que circulam entre os devotos. Os versos seriam baseados em certos livros "sagrados", como a Bíblia ou o Livro do Oriente (este "escrito" na época dos Magos). ${ }^{9}$ As tabelas encarnariam o fundamento, não só porque trazem em seu conteúdo as narrativas versificadas dos mitos que explicam a origem das festas, mas, principalmente, porque contêm, em sua própria forma, o testemunho do poder inventivo dos santos: quando realizaram sua viagem, os Magos também cantavam versos. Os textos são classificados de acordo com as diversas etapas do processo festivo. Há pelo menos 14 conjuntos de tabelas conhecidas: para a retirada, para as visitas, para a entrega etc.

As tabelas garantem que os demais foliões sejam considerados os auxiliares do capitão durante as atividades festivas. O conhecimento dos textos exige que cantadores e tocadores sigam rigorosamente as ordens do seu líder ao longo das apresentações - ainda que alguns possam, sempre 
fora deste contexto e de modo reservado, discordar dele. Era o que me dizia, certa vez, um folião de Silvianópolis, sul de Minas Gerais:

Na cantoria, o que o mestre canta lá na frente eu tenho que repeti o que ele falou, tenho que repeti igualzinho. Nem que ele teja xingano o dono da casa - não que eles faz isso, só de comparação - eu tenho que cantá. Depois eu posso i até o dono da casa e pedi desculpa, essas coisa... Mas na hora eu tenho que cantá. Minha obrigação é segui o guia na cantoria (Entrevista: Tião, Silvianópolis/MG).

Segundo a lógica do fundamento, o capitão ocupa necessariamente o primeiro plano da cantoria. Neste sentido, ele também é o guia dos foliões, aquele que aponta caminhos, indicando como e quando as coisas devem ser feitas. Aos demais cantadores, cabe "repetir" ou "responder" os versos que aquele proferiu. Por isso também alguns deles são nomeados "ajudantes de guia" ou "contra-guias": os primeiros, os auxiliares imediatos do cantador-chefe, os segundos, aqueles que cantam depois, reiterando os versos entoados. ${ }^{10}$

O fundamento ainda legitima outros aspectos da autoridade do capitão. Na medida em que o repertório da "doutrina" também abarca narrativas de acontecimentos que dão legitimidade a certas regras estabelecidas, conhecer um grande número de histórias ou "causos" contribui para que uma liderança possa comandar o comportamento dos seus ajudantes, controlar o uso de bebida alcoólica, apaziguar eventuais conflitos e exigir o respeito a certos padrões de conduta (Pereira 2011a). ${ }^{11}$ Segundo alguns capitães, por exemplo, o sentido "ensina" que os foliões, durante as jornadas, não carreguem mulheres na garupa dos seus cavalos. A autoridade da "doutrina" está ancorada na história dos Magos e nos exemplos retirados de casos supostamente ocorridos e testemunhados, guardados e retransmitidos pelos devotos. Dizia um antigo capitão urucuiano:

Tinha um folião... Ele saiu mais três companheiros. Era folia de quatro folião só. Num dia, ele deu garupa para uma mulher. No que ele tava indo, eles entraro numa grota, assim, funda. Quando saiu ele já tava sem voz. Os folião num podia mais fazer viagem... Não pode botar mulher na garupa, não. Nem que seja a mulher do folião, não pode. Tem exemplo do santo (Caderno de campo: Manoel de Oliveira, Urucuia/MG).

Responsável por liderar o trânsito entre diversos domínios sociais e cosmológicos, o folião-chefe incorpora o fundamento para se transformar na "face" visível do terno. A noção institui o capitão como o principal mediador 
da folia em relação aos santos (para quem os giros são devotados), aos imperadores (para quem os foliões trabalham), aos moradores (a quem os foliões visitam durante o giro), aos acompanhantes (com quem os foliões convivem durante o giro) e a outros tipos de interlocutores, tais como os organizadores de um evento "folclórico" (que ocorre fora de um giro).

\section{"O sistema de cada um"}

Ao final de um giro temporão de nove noites, um capitão urucuiano desentendeu-se com um de seus foliões. Naquela manhã de maio de 2008, o tocador pediu dinheiro emprestado ao imperador para resolver assuntos pendentes na cidade. O dono da festa respondeu que daria se tivesse, e solicitou que sua irmã fosse ver se havia uns trocados no quarto. A situação, em si mesma, parecia constrangedora. Em Urucuia, assuntos "de dinheiro" raramente são tratados em público, diante de outras pessoas. Pedir emprestado na "frente de gente" coloca aquele para o qual a solicitação é dirigida em posição difícil para eventualmente recusá-la.

O capitão, que assistia a tudo, resolveu então entrar na conversa. O folião-chefe dizia não achar correta a atitude do tocador. Suas razões, no entanto, pareciam outras, mais do que uma simples preocupação com a etiqueta cotidiana das pessoas. A folia, reiterava, é uma "coisa séria". Os foliões não fazem o giro por dinheiro. A devoção aos santos e o sentido do fundamento são seus guias durante as jornadas. Indiretamente, o capitão insinuava que o empréstimo solicitado era apenas uma maneira disfarçada de o folião exigir compensação financeira por seus serviços. Nada mais grave, tanto do ponto de vista do acusador como do acusado. O tocador, contrariado, respondeu rispidamente, antes de ir embora: "não é dado, não. Tô pedindo emprestado". Os presentes - que assistiram a toda a cena — não deixaram de fazer suas críticas à atitude do tocador (havia, decerto, alguma razão na fala do capitão). No entanto, o próprio líder cerimonial também foi criticado por ter falado com ele, naquele tom, na frente de todos.

Segundo uma etiqueta várias vezes enunciada pelos devotos, a autoridade de um capitão precisa ser exercida por meio de uma conversa reservada entre ele e o seu ajudante. Certa vez, um cantador me contava a história do seu tio, com quem começou a "foliar" ainda menino e de quem guardava a memória de ser um ótimo "chefe de folia". Além de ter o conhecimento litúrgico do sentido, seu parente havia construído para si mesmo um sistema capaz de "agradar" os tocadores. A fala do meu interlocutor não desconhecia o valor da autoridade, mas destacava que ela pode e deve ser exercida de 
modo distinto por diferentes capitães. O poder dos "chefes" não se baseia somente no conhecimento religioso acumulado através de anos e anos de aprendizado e prática. Não basta, noutros termos, encarnar a "doutrina"; faz-se necessário também saber como colocá-la em operação. Dizia meu interlocutor:

Meu tio que fazia direito. O sistema dele era bom. Ele chamava a gente num canto e falava assim: "cê tá gostando da mocinha, né, meu filho? Então, por que cê não deixa pra depois de tirar a toalha? Daí você namora. Espera um pouquinho. Vai só cozinhando agora". Isso que era legal. Não tinha essa de ficar cobrando na frente dos outros, não (Caderno de campo: Edvar, Urucuia/MG).

Um capitão, um imperador ou mesmo um simples morador (que tem o "seu jeito" de receber uma folia) podem ter modos próprios de conduzir as festividades, distintos de outros capitães, de outros imperadores, de outros moradores. A universalidade e a impessoalidade evocadas pela noção de fundamento têm como contraponto, então, a ideia geral de que as folias são marcadas por diversas singularidades. Uma festa comandada por uma pessoa ou realizada por um grupo familiar, por uma comunidade de vizinhança, noutro município ou mesmo num estado distante, vai ser necessariamente diferente. No limite, uma folia pode até estar sujeita a inúmeras transformações através dos tempos. Os "antigos", por exemplo, faziam festividades que se distinguiam daquelas realizadas pelos "novos". Do meu caderno de campo:

Ontem, uma patrocinadora de folias me falava que os foliões mais antigos não se cansavam facilmente. Na casa de seu pai, uma vez, um terno passou dois dias e não parou de cantar. "Hoje, folião só tá dormindo no pouso". Ela também disse que no giro "de antigamente" havia mais respeito porque mulher não andava acompanhando a folia. "O sistema de hoje é tudo diferente", concluiu (Caderno de campo, Urucuia/MG).

Na fala urucuiana, o sistema aparece como um contraponto à ideia de fundamento para explicar aos foliões e devotos os vários modos de se "fazer folia" e as razões dessa diversidade. ${ }^{12}$ As marcas distintivas de cada festa são testemunhos das diferenças estabelecidas entre pessoas e grupos: os "foliões novos", como no caso acima, são "mais moles" e "menos respeitosos" se comparados aos "antigos". Enquanto o fundamento é compartilhado por todas as folias, os sistemas, sempre no plural, operam discriminando e dividindo. Há o "sistema deles lá" e o "nosso aqui". As diferenças percebidas e reconhecidas seriam, então, frutos da ação humana. Se o fundamento é, por 
princípio, atividade divina ou divinizada (foram os Reis que o inventaram), o sistema parece evocar o trabalho dos homens, sujeito às contingências de toda ordem. Seu tempo é o tempo da humanidade, em contraponto à imutabilidade do mundo dos céus. Há o passado, o presente e o futuro dos sistemas. Eles nascem, crescem, envelhecem e, finalmente, morrem - eles estão sempre se modificando.

Em conjunto, as noções de fundamento e sistemas garantem que festas e produtores possam ser comparados, avaliados e julgados. ${ }^{13}$ Um jovem cantador urucuiano me contava, aos risos, uma experiência que teve junto às "folias do Acari" (localidade próxima a Urucuia): "É folião com borra [demais]! Eles andam o dia inteirinho! Cai um aqui [de bêbado ou cansado] e já tem outro ali [para ocupar seu lugar] (risos). O sistema deles é muito diferente" ${ }^{14} \mathrm{Meu}$ interlocutor estava claramente fazendo chacota dos cantadores "de lá". No entanto, no momento de destacar e comentar a atuação distinta de outros foliões, ele nunca deixou de reconhecer a unidade da "doutrina". Os tocadores do Acari também "fazem folia". Um devoto pode argumentar que um capitão urucuiano tem um sistema diferente do de outro capitão - formulação justa e bem entendida por todos. No entanto, o mesmo devoto nunca poderia dizer que o "fundamento" de um capitão não é igual ao de outro, com o risco de insinuar que um dos dois não "faz folia" do jeito certo, o que é outra forma de dizer que um dos dois não "faz folia" de forma alguma.

Reconhecer no outro uma forma diferente de se fazer folia também é uma maneira de produzir o seu próprio sistema. Verdadeiras "linhagens" podem, assim, ser construídas e percebidas. Certa vez, um tocador me dizia que um dos capitães mais conhecidos de Urucuia "foliava" influenciado pelos ensinamentos de um antigo guia, já falecido. A fala indicava uma profunda identificação entre os cantadores por meio do sistema: "Ivan aprendeu cantar folia mais o velho Manezim. É cria do Mazenim. É do sistema dele". A lealdade a um capitão, a um terno da "minha família", da "minha localidade", "da minha cidade" é, no limite, a lealdade a um sistema que ele(s) pode(m) representar (em oposição a outros). Dizia um cantador:

Inclusive nessa idade de 15 ano eu saía junto mais ele [meu tio]. Aí, quando chegou um certo tempo, aí separou. Aí o Jones ali fez um terno e ele [meu tio] ficou com outro. Aí eu era do terno de lá. Mas daí como o Jones é mais perto, eu vou ficar mais perto. Fiquei mais o Jones aqui. E aí tamo aí até hoje. E não saio fora do Jones, não. Até ganho convite pra ir em outras folia... Quando é época de folia aqui, chega pra mais de cinco convite aqui. "O, vem ajuntá mais eu?", "Vem ajuntá mais eu", "Não, cê é mais eu". Eu falo: "não, é aqui mais o 
Jones". Que já tem muito tempo que sai, então, se um fazer uma falhinha e o outro perceber, ele encobriu aquela falha ali. Os outros que fica de fora nem sabe daquela falha ali. Que nós já tamo treinado nesse sentido, né? E se eu sai lá com outro, eu completamente vou sair emprestado. Chega lá, se tiver qualquer uma falha, não tem como eu cubri, porque eu tô emprestado, não sei como que é o sistema deles. Aí, vai fazer feio, né? Aí, eu continuo aqui mais o Jones (Entrevista: José Rocha, Chapada Gaúcha/MG).

Na prática, as coisas consideradas como fundamento e sistema nunca podem ser determinadas de uma vez por todas. A articulação entre as noções parece ser mais importante do que os elementos que elas são contingencialmente capazes de abarcar. Aquilo que um devoto diz ser a "doutrina da folia" pode ser reinterpretado como uma singularidade de um terno por outro. E vice-versa. Numa ocasião, um capitão urucuiano justificava o fato de os seus foliões não utilizarem a rabeca durante as cantorias. "É do sistema antigo. Hoje, usa mais sanfona". A observação parecia banal: Cantar o reis é "do sentido" da folia, mas cantar fazendo uso ou não de uma rabeca é da ordem do sistema. Meses depois, no entanto, outro capitão me diria algo diferente:

É a viola, a rabeca e a caixa! Folia é só esses três instrumento, que vêm da época dos Reis Magos. Violão, sanfona, cavaquinho é coisa que o povo foi inventando... mas não é do sentido não, daquela mensagem que os Reis deixou pra nós (Caderno de campo, Urucuia).

O que acontece com um instrumento musical ocorre com outros elementos da folia. ${ }^{15}$ Posses inalienáveis dos capitães, as tabelas - expressões maiores do fundamento - raramente são emprestadas ou dadas a outros foliões. Sua transmissão está intimamente relacionada à manutenção e à atualização de laços familiares, de compadrio ou de amizade. Em determinados casos, a circulação dos textos pode, inclusive, contribuir para a constituição de novos vínculos sociais. Do meu caderno de campo:

Não são incomuns visitas mútuas entre foliões para trocas de saberes e experiências. Um folião da Vereda Grande louvava o fundamento de um conhecido capitão do distrito sede de Urucuia. Em 2007, ele foi à propriedade do chefe dos foliões para que este lhe ensinasse versos de uma folia. Dizia: "Eu conhecia muito ele. De ouvir falar, né? Lá na Vereda Grande o pessoal sempre falava dele, que conhece muitas tabelas de Reis, de todos os santos. Diz que ele aprendeu tudo lendo o Livro do Oriente até quando estava em cima do cavalo... Daí, eu 
fui lá e pedi pra ele uma tabela para saudação do altar de São Sebastião, que eu quero aprender. Lá na Vereda tem muito imperador que pede pra gente cantar. Então, eu quero aprender pra cantar também" (Caderno de campo, 2008).

A transmissão dos textos não ocorre sem que algumas modificações sejam realizadas. Neiva (2007), num curto mas interessante estudo sobre permanências e transformações nos modos de se pensar e fazer festas de folia no Entorno de Brasília, argumenta que as tabelas, ao serem repassadas de cantador a cantador, de capitão a capitão, sofrem inúmeras alterações: adaptações ortográficas, supressão ou inserção de versos etc. As mudanças, ao que parece, não são entendidas pelos devotos como um desafio ao fundamento. Há o reconhecimento por parte dos foliões de que o texto versificado é apenas um "guia" para a atuação ritual. O capitão, durante as cantorias, é livre para fazer alterações diversas. Era o que um folião, natural de Bonfinópolis, no noroeste mineiro, dizia à pesquisadora:

O guia tem que ter sempre aquele padrão de tabela. Não precisa ter as tabelas decoradas, não precisa ter tabela exata. Igual meu tio diz que não tem tabela, mas ele puxa uma tabela, ele sabe fazer a tabela. Isso tá na cabeça dele, ele já sabe a ordem, então ele inventa os versos de acordo com aquela ordem... (Neiva 2007:4).

A "ordem" faz referência à sequência do que deve ser cantado durante uma apresentação. Em Urucuia, o canto da "retirada da folia", por exemplo, é dividido, ao modo dos ritos de passagem, em três etapas distintas: o "cabeçalho" (onde são apresentados os personagens e anuncia-se o que se vai fazer no rito), a "passagem" do retrato, das toalhas e dos instrumentos (por meio da qual é ritualizada a entrega destes artefatos aos foliões), e a "despedida" (quando os rituais são finalizados e os cantadores anunciam o início de sua viagem) (Pereira 2011b). As tabelas, neste sentido, preveem os versos necessários a cada uma destas fases. Pode-se cantar o que o texto "ensina", sem medo de errar. No entanto, há muitas brechas para a improvisação, que diz respeito aos nomes dos moradores, à presença de outros santos no altar etc. (Pereira 2001a). Nas cantorias, o fundamento emerge como um conjunto estruturado de indicações (as fases do ritual). O sistema, pelo contrário, é o espaço aberto para a atividade criativa do cantador.

Não se trata de imaginarmos que o universo das folias urucuianas seja fracionado por inúmeras "religiões" particulares, cada qual com sua "crença" sobre o que deve ser um fundamento ou um sistema. Mais do que estabe- 
lecerem concretamente as diferenças entre aquilo que deve ser o mesmo para todas as folias e aquilo que pode mudar, as noções garantem a própria possibilidade de se pensar o que é o "mesmo" e o que é o "mudado" nos cantos e nas viagens dos tocadores. A relatividade entre os conceitos, um apontando para a totalidade, outro destacando a multiplicidade, garante a constituição de uma base sobre a qual as festas podem ser simultaneamente unificadas e diferenciadas. Os sistemas constituem-se a partir do fundamento que permite uma comparação com outro sistema: "Minha festa é diferente daquela festa", poderia dizer um devoto, destacando que a festa é o ponto comum entre dois eventos desiguais. O fundamento, por outro lado, existe como o devir festivo, a totalidade que só pode ser alcançada através das diferenças. Como sabem todos os devotos urucuianos, não há folia dotada de sentido que ocorra senão por meio da singularidade (do sistema) de um único capitão ou imperador.

\section{Chegando numa folia com passos (bem) desajeitados}

Na noite de 16 de janeiro de 2008, os foliões do distrito de Vereda Grande deram início ao "agradecimento da mesa", canto obrigatório de louvação oferecido em retribuição aos alimentos distribuídos pelos donos da festa durante o encerramento de uma folia. Ao meu lado, Gaspar (nome fictício), um dos mais renomados capitães do distrito sede de Urucuia, franziu a testa enquanto ouvia atentamente a apresentação. Como parte da "doutrina", o "agradecimento da mesa" é realizado por todas as folias urucuianas (Pereira 2013). Naquela noite, entretanto, meu companheiro achou a cantoria um tanto diferente. Em voz baixa, quase num muxoxo, ele me confessou: "Esses instrumentos tão meio desafinados, né?". Logo depois, arrematou: "O sistema deles aqui é no sistema velho, de afinar [a viola em] meia-quitarra. Não tem peito que aguenta".

O estranhamento não parou por aí. Por volta das $22 \mathrm{~h}$, os foliões da Vereda Grande iniciaram a "entrega da folia", que consiste na realização de um canto por meio do qual são finalizadas as atividades festivas. Segundo as regras estabelecidas pelo fundamento, o capitão e seu ajudante entoavam os versos da "tabela da entrega", que eram prontamente repetidos pelo contra-guia e seu ajudante. Os textos eram cantados segundo uma métrica bem estabelecida (ver Chaves 2006). Além disso, eles faziam uso de expressões que destacavam a distinção dos donos da casa e dos próprios tocadores ("senhor", "senhora", "nobre", "rainha" ou "rei"). Pronomes de tratamento, incomuns na fala cotidiana ("tu", "vossa" ou "vós"), também 
eram entoados. Os versos ainda incluíam os nomes próprios daqueles para os quais se cantava (ao invés de apelidos, muito usados no dia a dia). A "língua" dos reis, materializada na tabela, evocava assim a formalização (Pereira 2011a). Os proferimentos dos versos e as respostas (que repetiam o que foi dito pelo capitão) destacavam a redundância dos cantos, garantindo que as mensagens transmitidas fossem ouvidas e entendidas pelos devotos (ver Leach 1966). Segue um trecho da "entrega":

O meu nobre imperador

Com sua nobre rainha $(2 \mathrm{x})$

Vamos entregar a folia

Na porta desta lapinha $(2 \mathrm{x})$

[...]

Deus vos salve, imperador

Seu retrato [bandeira] aqui voltou $(2 \mathrm{x})$

Tava cumprindo essa promessa

Nesse mundo de meu Deus (2x)

Os cantadores e tocadores permaneceram em círculo durante toda a cantoria. Num texto anterior (Pereira 2011b), eu argumentei que a roda dos foliões possui qualidades sagradas, estabelecendo, em associação com o altar e a bandeira dos santos, os limites simbólicos do conjunto festivo (ver Diagrama 1) ${ }^{16}$ Estar no interior ou no exterior do círculo dos cantadores é estar, de alguma maneira, próximo ou distante do fundamento. Durante a cantoria, ninguém que permaneça fora da área de influência da roda dos foliões pode interferir no andamento dos cantos, sob pena de grave ameaça à sua eficácia. Eminentemente relacional, o círculo sagrado dos foliões ganha inteligibilidade em confronto com o exterior, onde falas e gestos informais são permitidos.

No entanto, tão logo os cantadores e tocadores da Vereda Grande se prepararam para realizar uma saudação individual do altar, Gaspar percebeu que eles não entoavam versos que entedia imprescindíveis ao encerramento da "entrega". ${ }^{17}$ A tabela, ali, era diferente. Influenciado pelo álcool, meu acompanhante começou, das margens da roda de foliões, sozinho e em voz alta, a proferir os versos que faltavam. "O reis", como diriam os devotos, "descontrolou". Gaspar cantava alto e "convenceu" (talvez por sua fama de bom capitão) os foliões do terno da Vereda Grande - que já se preparavam para sair - a acompanhá-lo. O chefe dos cantadores locais também não deixou de repetir, ainda que tropegamente, o que seu rival urucuiano entoava. 


\section{Diagrama 1 - A roda dos foliões e o movimento dos versos}

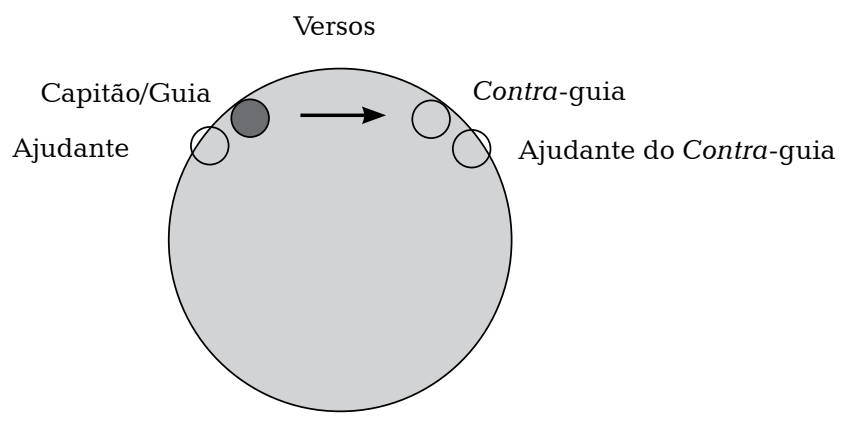

O reis - que ainda se seguiu por longos minutos — redundou estranho e terminou bastante desorganizado. Irritado com a intromissão indevida, o guia da Vereda Grande desculpou-se ironicamente com a audiência, assim finalizada a apresentação. "É, a gente morre e num sabe tudo...". Pouco tempo depois (não sei precisar quanto), Gaspar foi chamado a um canto por um amigo que tinha vindo com ele. Antes que eu pudesse chegar perto para saber o que estava acontecendo, ambos partiram, sem se despedirem. Dias passados, quando tive oportunidade de reencontrar o capitão, ele não tocou no assunto. Quando comentei sobre o que ocorrera, Gaspar respondeu lacônico, destacando que "cada lugar tem um sistema diferente". Ao que parece, ele sabia que sua performance na Vereda Grande não agradara a absolutamente ninguém.

Não era a primeira vez que observava um folião assistindo à apresentação de outros foliões para criticá-la. Entretanto, o mais comum era que meus interlocutores agissem com alguma discrição e cuidado para que os alvos dos seus comentários não pudessem escutar. A falação, como prática cotidiana de "falar mal" de alguém ou grupo (Dainese 2011), embora presente, não se faz evidente durante as apresentações rituais, sendo realizada nas imediações espaciais da cantoria ou após ela ser efetuada. Apenas em momentos de grande tensão, quando alguém "diz o que pensa" para que o outro (ou outros) possa (possam) ouvir, as críticas são feitas abertamente, antecedendo (ou mesmo exigindo) brigas que estão a ponto de emergir. ${ }^{18}$ Do ponto de vista formal, a falação também não parece competir diretamente com o canto entoado na roda dos foliões. Enquanto a primeira é quase um muxoxo informal - o que não significa ausência de regras (Comerford 2003) — as cantorias, bastante formalizadas, precisam ser ouvidas e entendidas. $\mathrm{O}$ fundamento exige regras específicas para que seja bem "entendido" pelos devotos. 


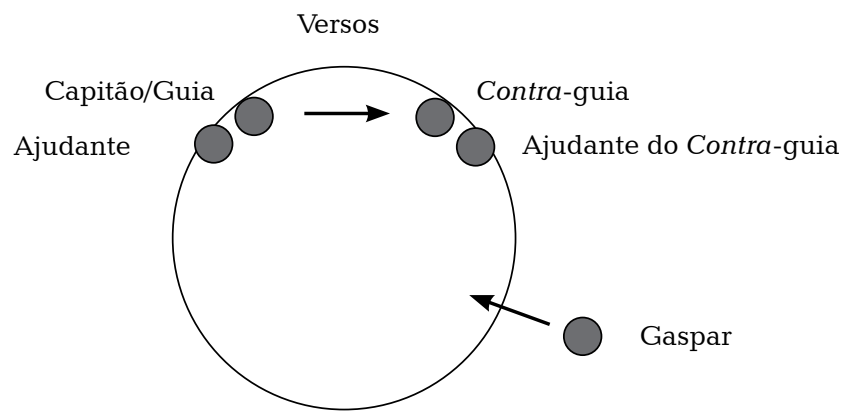

Durante sua realização, o reis institui o capitão/guia como um centro irradiador do fundamento. O canto transforma o líder dos tocadores num canal privilegiado de ligação com o alto (onde se encontram as divindades católicas) e com o passado mítico (de onde provêm as festividades). ${ }^{19}$ Assim, mais do que colocar frente a frente duas formas distintas de se fazer folia, Gaspar produziu uma duplicação espúria do sagrado (Diagrama 2). Na medida em que o legítimo centro irradiador dos versos - o capitão da Vereda Grande - foi abertamente desafiado, outro centro foi criado. Se o reis precisa estabelecer uma unidade que abarca (e apaga) as diferenças, o duplo, assim criado, anulava a proposta original. Não por outra razão, o canto terminou "descontrolado": os foliões da Vereda Grande não sabiam mais o que fazer.

\section{Um jogo de enquadramentos}

Em Urucuia, o reconhecimento da diversidade dos sistemas desempenha um papel fundamental na constituição das sociabilidades festivas. A ideia de que uma folia pode ser diferente de outra explica o interesse dos cantadores em acompanhar a realização de várias festas, produzidas por diferentes personagens. Através da circulação, os capitães podem aprender novos cantos (ou tabelas), afinações e formas de se comportar durante os cerimoniais. O mesmo ocorre com imperadores e moradores que, movimentando-se de folia em folia, são capazes de "aprender" com outros algo "novo" e "bom" para adicionar às suas festividades. Um imperador me explicou, certa vez, que ampliou em quase três metros quadrados a área da sala de sua casa para 
que os foliões e os devotos tivessem mais conforto. As mudanças, no entanto, não obedeciam apenas a razões da ordem prática ("pra ter mais espaço"). As casas bem equipadas para receber foliões e devotos são lembradas e imitadas como referências de "boas" festas e de renomados organizadores. Meu interlocutor planejou as obras em sua residência tendo como modelo a sala de um reconhecido patrocinador de folias urucuiano. "Você já viu a sala do Basílio? Então, ele é imperador forte. As folias dele sempre tá assim de gente, né? Precisa de espaço. E lá tem espaço pros foliões e o povo ficar".

As diferentes formas de se fazer folia também explicam as rivalidades entre foliões e ternos. As disputas ocorrem em dois níveis distintos. Num primeiro deles, um devoto pode destacar a diversidade para escolher o "tipo de folia" que mais lhe agrade: A afinação do Rio Abaixo é melhor para cantar do que a "Meia-Quitarra"; um terno de folia com poucos integrantes é menos bagunçado do que outro com muitos; tratar os foliões com respeito diante das pessoas é melhor do que desrespeitá-los publicamente etc. As avaliações, nesse sentido, não atentam contra o sentido da folia; elas não o colocam em suspeição. "Ir na festa dos outros" é ver o mesmo sendo feito de modo diferente. Unidos pelo fundamento, que lhes iguala como "cantadores que viajam em nome de um santo", os foliões competem por meio da diversidade.

Num segundo nível, o devoto pode até colocar em questão o fundamento que é apresentado por outro grupo. A disputa, nesses casos, evoca uma competição em que não há lugar para se conciliarem diferenças. A questão é da ordem do quantitativo: o importante é demonstrar que se "sabe mais" do fundamento do que o folião concorrente. Não foi outra a razão pela qual Gaspar não apenas se contentou em comentar as deficiências estritamente musicais (segundo seu ponto de vista) do terno da Vereda Grande, como também resolveu interferir ativamente no andamento dos cantos realizados. No primeiro caso, tratava-se de uma crítica ao sistema; no segundo, ao fundamento. O que alguns chamariam de inconveniência, nosso amigo resolveu entender como "ensinamento". Através do gesto intempestivo de adentrar sem ser chamado em uma roda de outros foliões, ele estava tentando mostrar como a cantoria deveria ser feita de acordo com aquilo que considerava ser o sentido da folia.

Embora força constitutiva, a percepção das diferenças é um problema que precisa ser enfrentado por uma festividade pautada pelas ideias de unidade, permanência e hierarquia. Não há nada pior para a reputação das festividades e dos seus organizadores do que a publicização dos desacordos ocorridos entre aqueles responsáveis por produzi-las (Pereira 2011a, 2012a). Para todos os efeitos, o dissenso precisa ser obscurecido durante as atividades rituais. No caso das cantorias, o reis propõe um único centro irradiador do 
sagrado, em detrimento da diversidade de saberes festivos. A estratégia não implica, claro, o fim das diferenças. Um folião sabe e muitas vezes expressa, através de muxoxos críticos ou de risadas, sua opinião a respeito daquilo que acabou de ver e ouvir. No entanto, como ele também deve saber, há a hora e o lugar para isto. A ênfase na unidade (ou na multiplicidade) é antes de tudo um problema de contexto. A questão é estabelecer mecanismos para que o registro da diferença não invada o lugar destinado ao fundamento (e vice-versa). O caso da Vereda Grande demonstra como a emergência da dissidência, no momento e em lugar inapropriados, pode atrapalhar a realização das cantorias.

Valerio Valeri (1994), a partir de Bateson (2000), afirma que o rito se caracteriza pela presença de "enquadramentos psicológicos" (ou "sinais metacomunicativos") que opõem as ações "enquadradas", ou "postas entre aspas", às ações ordinárias. ${ }^{20}$ Os sinais comunicam aos participantes de um cerimonial que os elementos enquadrados são "ficções": atividades que não estão no mesmo plano ontológico daquilo que representam ou estão em oposição. Segundo o autor, os meios mais frequentemente utilizados para enquadrar um rito são a formalidade do comportamento, o caráter fixo e repetitivo dos gestos, cores, perfumes, decorações especiais, rumores ou silêncios absolutos. Também são acionadas línguas ou níveis especiais de uma mesma língua, músicas e instrumentos específicos. Todos estes meios meios de comunicação, na linguagem de Tambiah (1985) — podem ter outras funções no rito, mas a sua presença é suficiente para identificar certos eventos como momentos extraordinários produzidos pela sociedade.

Além de assinalar aquilo que engloba, o enquadramento também teria a função de isolar as impressões produzidas pelas representações daquelas suscitadas pelo mundo que permanece "fora". O "efeito de realidade" do rito, sua eficácia, por assim dizer, estaria relacionado a um processo de obliteração. Diz o autor:

Desta forma, o enquadramento pode até funcionar como écran contra os indícios experienciais que contradizem o "efeito de realidade" das imagens que ele engloba, quando estas imagens são particularmente evocadoras (Valeri 1994:355). ${ }^{21}$

Os enquadramentos assumem, paradoxalmente, duas funções contraditórias: uma assinalando que o que contém é fictício; a outra fazendo esquecer que é. Nas folias urucuianas, os participantes têm sempre alguma consciência de que as imagens, os gestos e as palavras de uma cantoria são expressões de um sistema singular, único. No entanto, durante a execução dos cantos, a experiência extraordinária do fundamento surge quando o "equilíbrio entre 
as duas funções do enquadramento, entre a consciência da ficção e écran contra a realidade é alterado a favor deste último" (Valeri 1994:356).

A "doutrina" de um único capitão, noutros termos, só pode ser aceita como universal quando as diferenças entre os sistemas (de outros capitães) são mantidas escondidas, fora do quadro. O enquadramento garante a aceitação quase ficcional de um modelo parcial e relativo que, então, se transmuta em canal de mediação com a totalidade cósmica e social. Através da formalização das falas e dos gestos, além do uso de artefatos sagrados, as folias criam silêncios, de modo a reduzir ambiguidades provenientes da convivência - nem sempre pacífica — das diferentes maneiras de se pensar e fazer o ritual em Urucuia. As operações metacomunicativas funcionam de modo a garantir a heterogeneidade entre os domínios do fundamento e do sistema. Nesse sentido, a folia parece atualizar o modelo durkheimiano segundo o qual os rituais devem ser percebidos como atos coletivos responsáveis pela produção de totalidades cósmicas e sociais a partir de proibições que visam afastar ou obscurecer as fragmentações (Durkheim 2000). ${ }^{22}$

Nas margens temporais e espaciais dos cantos, no entanto, quando a informalidade substitui a formalidade, a diferença ganha preeminência. O dissenso não apenas é legítimo. Nas conversas entre devotos, ele chega a ser desejado. Um olhar através das margens, com seus comentários maliciosos, risos ou expressões de admiração, têm o poder de estranhar e destituir o sagrado de sua aura de totalidade e imutabilidade. Enquanto a cantoria produz a unidade, permitindo que um sistema parcial transforme-se ficcionalmente no vetor temporário de um fundamento, que precisa ser o mesmo para o "mundo todo", a falação parte do modelo universalizado - que unifica e permite a comparação entre os grupos - para chegar à singularidade, quando uma festa se torna diferente das outras.

Trata-se, então, de levarmos a sério o valor relativo - porque relacional — das "margens", da "liminaridade", durante os festejos urucuianos (Van Gennep 1979; Turner 1974). Noutros termos, a comunidade de folias ganha inteligibilidade a partir da troca alternada e controlada de perspectivas distintas entre o olhar desde o centro sacralizado dos ritos e a visada desde suas margens, onde a certeza da unidade festiva dá lugar ao dissenso e à fragmentação. Num polo festivo, poderíamos dizer, destaca-se a coerência; noutro, a ambivalência por meio da qual é subvertido o cenário de um mundo ordenado e unificado (Bakhtin 1999; Vilhena 1997). ${ }^{23}$ A folia é "uma só", mas também "são várias", sempre de acordo com o deslocamento dos olhares. Alternando perspectivas, os devotos urucuianos, por um lado, podem dizer, parafraseando Sahlins, que "as coisas devem preservar alguma identidade através das mudanças ou o mundo seria um hospício" (1999:190), enquanto 
por outro, ainda completariam: "e vice-versa", afinal, a identidade só faz algum sentido num mundo de diferenças.

Recebido em 24 de fevereiro de 2014

Aprovado em 25 de julho de 2014

Luzimar Paulo Pereira é bolsista PNPD/Capes do Programa de Pós-Graduação em Antropologia Social do Museu Nacional / UFRJ. E-mail: <mazinhop@ gmail.com>

\section{Notas}

${ }^{1}$ Uma leitura da devoção que não restringe o conceito à pura obrigação pode ser encontrada em Menezes (2004).

${ }^{2} \mathrm{O}$ material utilizado para a escrita deste artigo é fruto de trabalhos de campo realizados no município de Urucuia e região, entre os anos de 2006, 2007, 2008, 2013 e 2014.

${ }^{3}$ Cerqueira (2010) e Dainese (2011) destacam o papel que o "movimento" de pessoas, palavras e coisas desempenha na constituição de formas específicas de sociabilidade em determinadas áreas rurais de Minas Gerais. As folias, à sua maneira, parecem potencializar e tematizar o valor dos deslocamentos no estabelecimento de inúmeros vínculos sociais e cosmológicos.

${ }^{4}$ Em Urucuia, os giros de folia são dedicados aos mais variados santos do panteão católico. Há aqueles realizados aos Santos Reis (os mais importantes e valorizados pelos devotos), a São Sebastião, a São José, ao Bom Jesus da Lapa, a Nossa Senhora Aparecida e a Santa Luzia. Todas as folias se realizam em épocas precisas, de acordo com o calendário religioso que estabelece dias específicos para cada entidade: 6 de janeiro (Santos Reis), 20 de janeiro (São Sebastião), 19 de março (São José), 10 de agosto (Bom Jesus da Lapa), 12 de outubro (Nossa Senhora Aparecida) e 13 de dezembro (Santa Luzia).

${ }^{5}$ Em meados da década de 1990, as folias do distrito sede de Urucuia foram registradas através do trabalho da ONG paulistana Cachuêra!. O resultado desta pesquisa foi materializado em vídeo (Urucuia, um vão de nossas riquezas, dirigido por Angélica Del Nery) e CD (Famaliá: Sons do Urucuia). Além disso, um rico 
material em entrevistas permanece guardado no acervo da ONG, em São Paulo/SP. Os registros me foram muito úteis, sendo gentilmente cedidos por membros da ONG paulistana para minha pesquisa na região.

${ }^{6}$ Num texto recente, Brandão aborda o tema do fundamento, que ele descreve como "o repertório de relatos bíblicos, mitos, lendas derivadas e crenças religiosas do catolicismo popular" (2010:76-77). O fundamento está sempre associado a um rito em particular. Trata-se de um conjunto que explica: "a origem acreditada do rito universal; a origem e a história da prática do rito no Brasil, na região e na comunidade; o imaginário de acontecimentos e casos que garantem a sua legitimidade; as prescrições e proscrições rituais" (2010:76-77).

${ }^{7}$ Numa análise preliminar de um destes mitos fundadores, argumentei que a ideia de fundamento tem uma relação direta com o tema da troca de dádivas entre os homens e suas divindades (Pereira 2004). Vale notar que o catolicismo urucuiano (assim como o de outras regiões do país) ampliou e enriqueceu de detalhes uma passagem relativamente curta da Bíblia.

${ }^{8}$ Diz Brandão a respeito das folias: "Ao constituir o espaço simbólico da jornada dos reis, a Folia transporta para dentro dele, com nome e proclamações de bênçãos: as pessoas, os animais, os objetos e as trocas do próprio mundo camponês. Assim, os mesmos homens do trabalho agrário cotidiano aparecem por sete dias revestidos de cumplicidade com os mitos populares de uma história sagrada que todos conhecem por ali. Na medida em que realizam a jornada e cantam de casa em casa, eles reconstituem tanto essa história, quando os gestos e as palavras de suas pequenas estórias, tal como acreditam que tenham acontecido e tal como supõem que reproduzem, com uma fidelidade que se perde aos poucos, mas que é legítima, sem dúvida alguma" (1981:40-41).

${ }^{9}$ Um folião do Entorno de Brasília confirma essa versão: “Meu avô já cantava, e o pai do meu avô cantava. A tabela veio do Livro do Oriente [...]. As tabelas vieram do Livro do Oriente, só que ninguém nunca viu o tal do Livro do Oriente, não sabe se existiu... Muita gente tem crença, e eu também acredito, que elas vieram ainda dos três Reis Magos, só que mudou muito - o tempo vai mudando e teve adaptações" (Neiva 2007:8).

${ }^{10}$ A noção de guia também parece referendada pelo mito de origem das folias. Quando em viagem, os Magos foram "guiados" por uma estrela. O astro, segundo interpretações nativas, seria uma transmutação do Anjo Gabriel, enviado por Deus para indicar os caminhos que os levariam para Belém. Nesse sentido, guiar não apenas evoca o deslocamento horizontal, mas implica igualmente uma mediação necessária entre o alto e o baixo, entre "este mundo" e o "outro mundo", do céu.

${ }^{11}$ Nesse sentido, as noções de guia e capitão, embora se aproximem, não são necessariamente equivalentes. Enquanto o capitão deve ser obrigatoriamente um guia, um folião pode "cantar de guia" sem ser capitão (porque lhe falta autoridade para "mandar" nos demais cantadores). No limite, ser capaz de cumprir o papel de 
condutor dos cantos é condição para alguém se tornar um capitão, embora não seja o suficiente para concluir esta transformação.

${ }^{12}$ Ana Cerqueira (2013) apresenta a noção de sistema assim como presente entre os habitantes de um pequeno agrupamento rural do município da Chapada Gaúcha. Ali, o conceito, da maneira como é usado cotidianamente em Urucuia, define "povos, famílias e pessoas; formam unidades intrínsecas às variáveis da sorte, dos deslocamentos geográficos e existenciais - tão imprevistos quanto inevitáveis ao sistema - que se dão ao longo dos ciclos de nascimentos, casamentos e mortes" (Cerqueira 2013:2).

${ }^{13}$ Ao circular por outras festas e observar outros devotos, os participantes dos festejos percebem que o "seu" jeito de fazer folia não é único, mas apenas um dentre vários. O reconhecimento das diferenças está na base de cálculos políticos acionados nos momentos de se exercer um sistema, tanto para se estar disposto a "relaxar" certas regulamentações específicas, como para se marcar uma posição diante de outros. "O meu sistema", dizia um líder ritual, "é esse aqui. Quem não gostar que vai caçar rumo com outro capitão". O risco para o devoto, nestes casos, é ver o seu sistema associado à rígida hierarquia da imposição e ele "sistemático" demais. Ao invés de se abrir a algum tipo de diálogo, o "sistemático" é aquele que não se permite interagir com qualquer modelo diferente do seu.

${ }^{14}$ Os limites do sistema parecem terminar no "descontrole" quando uma folia deixa de ser folia. No início de 2014, os devotos do distrito sede de Urucuia comentavam a respeito de um terno que girava pelo seu pequeno centro urbano. Embora o capitão fosse reconhecido como capaz de entoar diversas tabelas, o grupo era criticado por andar bêbado pelas casas. No limite, quando se referiam ao terno como "de folia", invariavelmente os devotos prontamente sorriam, como se dissessem: "terno de folia? que nada...".

${ }^{15}$ Um conhecido capitão da Chapada Gaúcha me disse achar "errado" o fato de algumas folias fazerem uso do "palhaço" (personagens mascarados que acompanham os cantadores) em suas jornadas. Segundo ele, o "mascarado" (que, para determinados grupos, "representa" a figura de Herodes, o rei dos judeus que tentou assassinar o Menino Jesus) evocava o diabo. "Não é o sentido", dizia. Os foliões que fazem uso de palhaços, no entanto, discordariam veementemente do meu interlocutor, como notou Daniel Bitter (2008), no caso das festas de folia da Mangueira, no Rio de Janeiro. Ali, o mascarado também é parte do fundamento.

${ }^{16}$ A cantoria é um rito cuja operacionalidade é garantida pela dissolução temporária das fronteiras entre o material e imaterial, o corpo e o espírito, a linguagem falada e a poética cantada. Os gestos, os posicionamentos dos corpos, as manipulações de objetos sagrados e os proferimentos de palavras se misturam para produzir um enquadramento semântico em que operações metafóricas e metonímicas, de contágio e de semelhança, são postas em operação (Pereira 2011b).

${ }^{17}$ Tratava-se de hinos transmitidos através da atuação da Igreja Católica no município. Enquanto os cantadores e tocadores da sede municipal de Urucuia parecem ter adotado os cantos, os grupos da Vereda Grande, não. 
${ }^{18}$ Certa vez, os foliões estavam realizando, como de praxe, sua visita a uma moradia. Um folião concorrente, que tinha a fama de ser encrenqueiro e beber muito, estava acompanhando. Numa casa, o cantador criticou abertamente o canto realizado pelos foliões que estavam no giro. Depois, passou a criticar o capitão que, segundo dizia, "cantava muito alto". No final da visita, o imperador, que observava o seu comportamento, chegou a ameaçá-lo. O folião tentou contra-argumentar. O imperador, no entanto, retrucava: "estou pelejando com você desde que a gente saiu de casa hoje. Mas cê não se ajeita". O prosa-ruim foi aconselhado a ir-se embora, para evitar maiores confusões (Caderno de campo, Urucuia/MG).

${ }^{19} \mathrm{O}$ centro e a hierarquia também são tematizados em diversos momentos dos giros de uma folia (Pereira 2011a, 2012b, 2013)

${ }^{20}$ Gregory Bateson (2000) defende a ideia de que a comunicação verbal humana pode operar em vários níveis de abstração. Toda mensagem apresenta um nível denotativo (de conteúdo), um nível metalinguístico e um nível metacomunicativo. O nível metalinguístico diz respeito ao modo como a mensagem repensa a própria linguagem, enquanto o metacomunicativo envolve elementos que definem a própria relação estabelecida entre os falantes. Desta maneira, Bateson enfatiza que, mais do que conteúdos, enunciados comportam marcas (enquadramentos) que balizam a interação estabelecida.

${ }^{21}$ Poder-se-ia demonstrar esta proposição analisando, por exemplo, os ritos mágicos, nos quais a consciência do caráter fictício e em todo o caso "menos real" das atividades rituais, se bem que inibida, nunca está ausente e até influencia a crença, dando-lhe subterraneamente a forma (Valeri 1994). Como pensa Mauss (2003), o fato de a magia ser potencialmente um embuste é parte da crença na própria magia.

22 "A oposição desses dois gêneros irá, aliás, traduzir-se exteriormente por um signo visível que permitirá reconhecer com facilidade essa classificação muito especial, onde quer que ela exista. Como a noção de sagrado está, no pensamento dos homens, sempre e em toda parte separada da noção de profano, como concebemos entre elas uma espécie de vazio lógico, ao espírito repugna invencivelmente que as coisas correspondentes sejam confundidas ou simplesmente postas em contato, pois tal promiscuidade ou mesmo uma contiguidade demasiado direta contradizem violentamente o estado de dissociação em que se acham tais ideias nas consciências. A coisa sagrada é, por excelência, aquela que o profano não deve e não pode impunemente tocar. Claro que essa interdição não poderia chegar a ponto de tornar impossível toda comunicação entre os dois mundos, pois, se o profano não pudesse de maneira nenhuma entrar em relação com o sagrado, este de nada serviria. Mas tal relacionamento, além de ser sempre, por si mesmo, uma operação delicada, que requer precauções e uma iniciação mais ou menos complicada, de modo nenhum é possível sem que o profano perca suas características específicas, sem que se torne ele próprio sagrado num certo grau e numa certa medida. Os dois gêneros não podem se aproximar e conservar ao mesmo tempo sua natureza própria" (Durkheim 2000:23-24).

${ }^{23}$ Luis Rodolfo Vilhena entende que a obra de Bakhtin destaca, por meio da noção de ambivalência, a capacidade da cultura popular de simbolizar a ambiguidade em situações e objetos (Vilhena 1997:52). 


\section{Referências bibliográficas}

BAILEY, Frederick G. 1971. Gifts and posion: the politics of reputation. New York: Schocken Books.

BAKHTIN, Mikhail. 1999. A cultura popular na Idade Média e no Renascimento: o contexto de François Rabelais. São Paulo: Hucitec; Brasília: Editora da Universidade de Brasília.

BATESON, Gregory. 2000. Steps to an ecology of mind. Chicago: University of Chicago Press.

BITTER, Daniel. 2008. A bandeira e a máscara: estudo sobre a circulação de objetos rituais nas folias de Reis. Tese de Doutorado, PPGSA/IFCS/UFRJ. BRANDÃO, Carlos Rodrigues. 1981. Os sacerdotes da viola. Petrópolis: Editora Vozes. 2010. Prece e folia, festa e romaria. Aparecida, SP: Ideias \& Letras.

CAVALCANTI, Maria Laura V. C. 2006. Carnaval carioca: dos bastidores ao desfile. Rio de Janeiro: EdUFRJ.

CERQUEIRA, Ana Carneiro. 2010. O "povo" parente dos Buracos: mexida de prosa e cozinha no cerrado mineiro. Tese de Doutorado, PPGAS/Museu Nacional/ UFRJ.

2013. O sistema da mexida de cozinha: de que riem eles? [Mimeo].

CHAVES, Wagner. 2006. "Recebeis meu Bom Jesus com sua nobre folia: reflexões sobre a eficácia do canto nas folias norte-mineiras do alto-médio São Francisco". Textos Escolhidos de Cultura e Arte Populares, 3(1):81-99. COMERFORD, John Cunha. 2003. Como uma família: sociabilidade, territórios de parentesco e sindicalismo rural. Rio de Janeiro: Relume Dumará.

CONTINS, Márcia \& GONÇALVES, José Reginaldo Santos. 2008. "A escassez e a fartura: categorias cosmológicas e subjetividade nas festas do divino espírito santo entre imigrantes açorianos no Rio de Janeiro". In: M.L.V.C. Cavalcanti \& J.R.S. Gonçalves (orgs.), Ritos e sociabilidades festivas. Rio de Janeiro: Contra Capa. pp. 11-36.

CORRÊA, Roberto; SAENGER, Juliana \& MARCHI, Lia. 2002. Tocadores: homem, terra, música e acordes. Curitiba: Olaria.

DAINESE, Graziele. 2011. Chegar ao cerrado mineiro: hospitalidade, política e paixões. Tese de Doutorado, PPGAS/ Museu Nacional/UFRJ.

DURKHEIM, Émile. 2000. As formas elementares da vida religiosa. São Paulo: Martins Fontes.

LEACH, Edmund. 1966. "Ritualization in man?". In: Sir Julian Huxley (org.), A discussion on ritualization of behavior in animals and man. Philosophical Transactions of the Royal Society of London, Series B, 251(772):403-408 (London Royal Society).

MAUSS, Marcel. 2003. Sociologia e antropologia. São Paulo: Cosac \& Naif. MENEZES, Renata de Castro. 2004. A dinâmica do sagrado: rituais, sociabilidade e santidade num convento do Rio de Janeiro. Rio de Janeiro: Relume Dumará.

NEIVA, Ivany Câmara. 2007. "Devoção na folia: comunicação popular, permanências e transformações". Intercom Sociedade Brasileira de Estudos Interdisciplinares da Comunicação, XXX Congresso Brasileiro de Ciências da Comunicação - Santos. Disponível em: http://www.adtevento.com.br/ intercom/2007/resumos/R0195-2.pdf. Acesso em: 19/08/2008.

PEREIRA, Luzimar Paulo. 2004. Os andarilhos dos Santos Reis: um estudo etnográfico sobre Folia de Reis, bairro 
rural e sistemas de prestações totais. Dissertação de Mestrado em Desenvolvimento, Agricultura e Sociedade, CPDA/UFRRJ.

. 2008. "A viola do diabo: notas sobre narrativas de pactos demoníacos no norte e noroeste mineiro". In: E. Giumbelli; J.C.V. Diniz \& S. Cambraia (orgs.), Leituras sobre música popular: reflexões sobre sonoridades e cultura. Rio de Janeiro: 7Letras. pp. 380-396. . 2011a. Os giros do sagrado: um estudo etnográfico sobre folias em Urucuia, MG. Rio de Janeiro: Editora 7Letras. . 2011b. "Bendito Louvado Seja: notas etnográficas sobre os cantorios religiosos das folias de Urucuia-MG". Textos Escolhidos de Cultura e Arte Populares (Impresso), 08:161-177.

. 2011c. "Promessa, consideração e trato nas festas de folia em Urucuia-MG". Antropolítica, 31:97-122.

. 2012a. "Os sacrifícios da carne: a morte do gado e a produção dos banquetes nas folias de Urucuia MG". Religião \& Sociedade, 32:71-96.

. 2012b. "No giro: as folias como peregrinações rituais". Interseções, 14:25-45. . 2012c. "As vicissitudes da fama". Revista de Antropologia , 55(2):1047-1083. . 2013. "À mesa com os santos: a noção de 'fartura' nas folias de Urucuia (Minas Gerais)". In: J.R.S. Gonçalves; R.S. Guimarães \& N. Bitar (orgs.), A alma das coisas: patrimônios, materialidade e ressonância. Rio de Janeiro: Mauad. pp. 155-184.

SAHLINS, Marshall. 1999. Ilhas de história. Rio de Janeiro: Zahar Editores. SIMMEL, George. 1971. On individuality and social forms. Chicago: The University of Chicago Press.

TAMBIAH, Stanley Jeyaraja. 1985. Culture, thought and social action. Cambridge: Harvard University Press.

TURNER, Victor. 1974. O processo ritual. Petrópolis: Ed. Vozes.
VALERI, Valerio. 1994. "Rito". In: Enciclopédia Einaudi, 30. Religião-rito. Lisboa: Imprensa Nacional/ Casa da Moeda. pp. 325-359.

VAN GENNEP, Arnold. 1978. Os ritos de passagem. Petrópolis: Vozes.

VERNANT, Jean Pierre. 1990. "Aspectos míticos da memória e do tempo". In: Mito e pensamento entre os gregos. Rio de Janeiro: Paz e Terra. pp. 105-148.

VILHENA, Luis Rodolfo. 1997. Ensaios de antropologia. Rio de Janeiro: EdUERJ. 


\section{Resumo}

Em Urucuia, norte de Minas Gerais, os conceitos locais de fundamento e sistema evocam, respectivamente, as semelhanças e as diferenças entre as festas de folia realizadas em um grande circuito festivo. Descrevendo a circulação de devotos por diversas festas, procuro neste artigo analisar os usos narrativos e festivos destas noções para destacar o modo como elas estão relacionadas a processos específicos de produção e contestação de uma experiência sagrada calcada nas ideias de unidade e totalidade. Ao proporem que as festas sejam simultaneamente uma e várias, que sejam permanentes e mutantes, que sirvam às comunidades e aos interesses individuais, os devotos põem em jogo demarcadores rituais capazes de produzir contextualmente a confirmação do poder totalizador e atemporal das folias ao mesmo tempo em que abrem espaço para a sua dissolução. Palavras-chave Sagrado, Rituais, Movimento, Comunidade, Folia.

\section{Abstract}

In Urucuia (Northern Minas Gerais), the local concepts of "fundamento" and "sistema" refer, respectively, to the similarities and differences between the feasts held in a festive circuit. Starting from a description of the movement of devotees from feast to feast, I analyze the narrative and festive uses of these notions in order to highlight how they relate to processes of production and to the contestation of sacred experience grounded on notions of unity and wholeness. According to devotees, the various feasts are at the same time one and several, enduring and changing, serving community and individual interests. They use ritual markers aiming both to confirm the "folias" atemporal totalizing power and to allow its possible dissolution.

Key words Sacred, Rituals, Movement, Community, Folia. 